\title{
COMPARATIVE STUDY BETWEEN THE MICROBIOLOGICAL QUALITY OF COMMERCIAL AND HOMEMADE LABENAH
}

\author{
MARWA M.N. EL-GENDI \\ Animal Health Research Institute, Assiut Lab.
}

Email: moazahmednofel@yahoo.com

Assiut University web-site: www.aun.edu.eg

\section{ABSTRACT}

Received at: 30/9/2015

Accepted: 22/10/2015
A total of 50 commercial and homemade Labenah samples were collected randomly from supermarkets and houses ( $n=25$ for each product) in Asiut Governorate. It was concluded that the average of total counts of yeasts and molds and total coliforms were $8.8 \times 10^{2}$ and $9.6 \times 10^{2} \mathrm{cfu} / \mathrm{g}$ in commercial labneh and $6 \times 10^{2}$ and $7.6 \times 10^{4} \mathrm{cfu} / \mathrm{g}$ in homemade labenah, respectively. Pathogenic E.coli could be isolated in percentage of $28 \%$ from homemade one. The isolated pathogenic E.coli could be serologically identified to $O 103: H 2(E H E C), O 26: H 11(E H E C), O 125: H 21(E T E C), O 26$ : H11(EHEC), O55: H7(EPEC), O91(EPEC) and O125: H21(EHEC). Serratialiquefaciens, Klebsiella pneumonia, Providenciarettgeri, Proteus mirabilis, Enterobacteraerogenes and Serratiamarcescens could be isolated and identified in percentages of $4 \%, 12 \%, 12 \%, 12 \%, 12 \%$ and $4 \%$ in the examined samples of homemade labenah. Coliforms which could be detected in examined samples of commercial labenah were Citrobacterdiversus, Proteus mirabilis and Enterobacteraerogenes in percentages of $4 \%, 4 \%$ and $4 \%$, respectively. The results obtained show that labenah samples collected from Supermarkets were safer than that made at home.

Key words: Microbiological quality, Commercial, Homemade labenah

\section{INTRODUCTION}

Modern socio-economic changes mean that some traditional technologies for the production of fermented foods might eventually be lost together with the associated microorganisms (Akabanda et al., 2013). This underscores the importance of studying indigenous fermented products for their microbiota which might yield technologically important species and strains. Microorganisms present in traditionally fermented milk products have been documented in various studies (Gonfa et al., 1999; Beukes et al., 2001; Lore et al., 2005; El-Baradei et al., 2008; Mathara et al., 2008; Njage et al., 2011; Akabanda et al., 2013).

Nutritional and therapeutic properties of labenah are considered similar to or even better than those of yogurt. Labenah has 2.5 time's higher protein content, $50 \%$ more minerals, and a considerably larger number of viable microorganisms than common yoghurt (Nsabimana et al., 2005). In addition, the lactose concentration of labneh is low (approximately 6\%) due to its fermentation into lactic acid, which makes it more suitable for use by lactose intolerant individuals (Nsabimana et al., 2005 and Özer and Robinson, 1999). Due to its high total solids content, labenah may be considered a suitable matrix for probiotics since it offers protection when added to them (Abd El-Salam et al., 2011). The high microbial load of labenah ccoupled with the packaging and storage conditions, result in the formation of off-flavours and undesirable physicochemical changes that eventually lead to rejection of the product (Muir and Banks, 2000).

Labenah is a white to creamy paste product that has a smooth texture, with a taste crossing between sour cream and cottage cheese and a characteristic sharp flavor that is largely modulated by diacetyl produced during fermentation (Varnam and Sutherland, 1994; Tamime and Robinson, 1999). Concentrated yogurt, known as labneh in the Middle East, is widely consumed, chiefly as a sandwich spread, in the Middle East and Balkan regions (Tamime et al., 1989 and Özerand Robinson, 1999). Labneh is produced by removing a proportion of the whey from cow's milk yogurt until fat and total solids contents of 9 to 11 and 23 to $25 \%$ are attained, respectively (Tamime and Robinson, 1999). 
In Lebanon, and other Middle Eastern countries, labenah is produced by straining yogurt in cloth bags to the desired total solids level. The product is packaged in plastic containers that prevent access of light and air, and displayed under refrigeration (5 to $7^{\circ} \mathrm{C}$ ) in retail outlets. The presence of live starter bacteria and yeast and mold contaminants (Salji et al., 1987) coupled with packaging/storage conditions lead to the formation of off-flavors and other undesirable physicochemical changes that eventually lead to product failure (Muir and Banks, 2000). The stated shelf life of cloth-bag labenah, produced by major dairy processors, is between 14 and $21 \mathrm{~d}$ and is largely based on commercial experience. The variation in quality of Labneh (yoghurt cheese) in different countries is due to the variation of starter cultures used (Sharaf et al., 1996).

The product may be considered as intermediate between conventional fermented milks and high moisture, unripened soft cheese such as quarg (Varnam and Sutherland, 1994).

Labenah is produced by strains of thermophilic lactic acid bacteria (LAB), which ferment the lactose present to produce organic acids, mainly lactic acid (El-Samragy, 1997). Industrially, excess liquid is removed from the yoghurt by mechanical separators (Tamime and Robinson, 1999). The shelf life of traditional labenah is short, even if stored at low temperatures. This may be due to the sanitary problems usually associated with the cloth bags used in its production and due to unhygienic handling of the product, which increases microbial contamination (El-Samragy, 1997).

Coliforms and E. coli are often used as marker organisms. Recovery and counting of E. coli is used as reliable indicator of fecal contamination and indicates a possible presence of enteropathogenic and/or toxigenic microorganisms which constitute a public health hazard. E. coli is one of the main inhabitants of the intestinal tract of most mammalian species, including humans and birds. Most E. coli are harmless, but some are known to be pathogenic bacteria, causing severe intestinal and extra intestinal diseases in man (Kaper et al., 2004).

Strains of E. coli are traditionally characterized by serological identification of somatic $\mathrm{O}$, flagellar $\mathrm{H}$, capsular K, and fimbrial $\mathrm{F}$ antigens (Quinn et al., 2002 and Gyles et al., 1993). Differentiation of pathogenic strains from normal flora strains depends on the identification of virulence characteristics. E.coli strains can further be classified according to the presence of virulence factors such as enterotoxigenic $E$. coli (ETEC), attaching and effacing E.coli (AEEC), enteropathogenic E. coli
(EPEC), enterohemorrhagic E. coli (EHEC), and Shiga toxin-producing E. coli (STEC or VTEC) (Franck et al., 1998 and Nagy and Fekete 1999). Virulence factors associated with strains of $E$. coli include adhesions, toxins, cell wall, capsule production, and serum resistance (Gyles et al., 1993).

The labenah samples were microbiologically examined in order to determine whether they were hygienically safe to be consumed by customers or not.

\section{MATERIALS and METHODS}

\section{A) Collection, preparation and serial dilutions of samples:}

A total of fifty random samples of commercial and homemade labneh were collected from different shops and supermarkets and houses (25 samples of each), respectively. The commercial samples were still valid for consumption for 6 months from production time and they were transferred to the laboratory in their packages to be analyzed microbiologically to evaluate their quality. Eleven grams of the prepared samples were mixed with 99 $\mathrm{ml}$ of sterile $0.1 \%$ peptone water and thoroughly mixed to give a dilution of $1 / 10$, and then tenfold serial dilutions were carried out according to (A.P.H.A., 1992).

B) Experimental techniques:

1) Enumeration of total yeasts and molds count according to Harrigan and MacCance (1976) by using malt extract agar (containing $500 \mathrm{mg}$ each of chlortetracycline and HCL chloramphenicol).

2) Enumeration of total coliform count according to Ray and Speck (1978) by using violet red bile glucose agar.

3) Isolation and identification of E. coliaccording to Dilielo (1982).

A portion $(10 \mathrm{~g}$ or $10 \mathrm{ml})$ from the centre of each sample was extracted aseptically and homogenized with $90 \mathrm{ml}$ sterile enrichment MacConkey broth. The enriched sample was cultured on selective medium Levine Eosin Methylene Blue (EMB) agar and incubated at $37{ }^{\circ} \mathrm{C}$ for 24 hours. Morphologically typical colonies (at least 4 / plate) producing metallic sheen were taken into nutrient broth for further identification.

Biochemical tests were performed to confirm E.coli using Gram staining, Catalase test, Indole, Methyl red, Voges- Proskauer test, Nitrate reduction, Urease production, Simon citrate agar, and various sugar fermentation tests. 


\section{Serodiagnosis of E.coli:}

The isolates were serologically identified according to Kok et al. (1996) by using rapid diagnostic E.coli antisera sets (DENKA SEIKEN Co., Japan) for diagnosis of the Enteropathogenic types.

\section{Technique:}

- Two separate drops of saline were put on a glass slide and a portion of the colony from the suspected culture was emulsified with the saline solution to give a smooth fairly dense suspension.

- To one suspension, control, one loopful of saline was added and mixed. To the other suspension one loopful of undiluted antiserum was added and tilted back and forward for one minute.

- Agglutination was observed using indirect lighting over a dark background. When a colony gave a strongly positive agglutination with one of the pools of polyvalent serum, a further portion of it was inoculated onto a nutrient agar slant and incubated at $37^{\circ} \mathrm{C}$ for 24 hours to grow as a culture for testing with mono-valent sera.

- A heavy suspension of bacteria from each slope culture was prepared in saline, and slide agglutination tests were performed with the diagnostic sera to identify the $\mathrm{O}$-antigen.

- The diagnostic E.coli antisera sets used for identification include the following sets:

Set 1 : 0 - antisera:

Polyvalent antisera 1: O1, O26, O86a, O111, O119, O127a and $\mathrm{O} 128$.

Polyvalent antisera 2: O44, O55, O125, O126, O146 and O166.

Polyvalent antisera 3: O18, O114, O142, O151, O157 and O158.

Polyvalent antisera 4: O2,O6, O27, O78, O148, O159 and O168.

Polyvalent antisera 5: O20, O25, O63, O153 and O167.

Polyvalent antisera 6: O8, O15, O115 and $\mathrm{O} 169$.

Polyvalent antisera 7: O28ac, O112ac, O124, O136 and $\mathrm{O} 144$.

Polyvalent antisera 8: O29, O143, O152 and O164.

Set 2: H- sera.

H2, H4, H6, H7, H11, H18 and H21.

\section{RESULTS}

Table 1: Statistical analytical results of total yeast and molds count of the examined samples.

\begin{tabular}{cccccc}
\hline \multirow{2}{*}{ Sample } & \multicolumn{2}{c}{ Positive samples } & \multicolumn{3}{c}{ Count/g } \\
\cline { 2 - 6 } & No. & $\%$ & Min. & Max. & Average \\
\hline $\begin{array}{c}\text { Commercial Labenah } \\
\text { (No. :25) }\end{array}$ & 5 & $20 \%$ & $<100$ & $5 \times 10^{3}$ & $\mathbf{8 . 8 \times 1 0 ^ { 2 }}$ \\
\hline $\begin{array}{c}\text { Homemade Labenah } \\
\text { (No.:25) }\end{array}$ & 7 & $28 \%$ & $<100$ & ${ }^{4} \times 10^{3}$ & ${ }^{6} \times 10^{2}$ \\
\hline
\end{tabular}

No. : Number of examined samples

Table 2: Statistical analytical results of total coliforms count of the examined samples.

\begin{tabular}{cccccc}
\hline \multirow{2}{*}{ Sample } & \multicolumn{2}{c}{ Positive samples } & \multicolumn{3}{c}{ Count/g } \\
\cline { 2 - 6 } & No. & $\%$ & Min. & Max. & Average \\
\hline $\begin{array}{c}\text { Commercial Labenah } \\
(\text { No. :25) }\end{array}$ & 7 & $28 \%$ & $<100$ & ${ }^{9}$ X10 & ${ }^{3.6} \mathbf{X 1 0}^{2}$ \\
\hline $\begin{array}{c}\text { Homemade Labenah } \\
\text { (No. :25) }\end{array}$ & 18 & $72 \%$ & $<100$ & ${ }^{3.15} \mathbf{X 1 0}^{5}$ & ${ }^{7.6} \times 10^{4}$ \\
\hline
\end{tabular}

No. : Number of examined samples 
Table 3: Incidence of some microorganisms could be isolated from the examined.

\begin{tabular}{lcccc}
\hline Microorganisms & \multicolumn{2}{c}{ Commercial Labenah } & \multicolumn{2}{c}{ Homemade Labenah } \\
\cline { 2 - 5 } Products & No./25 & $\%$ & No./25 & $\%$ \\
\hline Pathogenic E. coli & $\mathbf{0}$ & $\mathbf{0}$ & $\mathbf{7}$ & $\mathbf{2 8 \%}$ \\
Serratialiquefaciens & $\mathbf{0}$ & $\mathbf{0}$ & 1 & $\mathbf{4 \%}$ \\
Klebsiella pneumonia & $\mathbf{0}$ & $\mathbf{0}$ & $\mathbf{3}$ & $\mathbf{1 2 \%}$ \\
Providenciarettgeri & $\mathbf{0}$ & $\mathbf{0}$ & $\mathbf{3}$ & $\mathbf{1 2 \%}$ \\
Proteus mirabilis & $\mathbf{0}$ & $\mathbf{0}$ & $\mathbf{3}$ & $\mathbf{1 2 \%}$ \\
Enterobacteraerogenes & $\mathbf{0}$ & $\mathbf{0}$ & $\mathbf{3}$ & $\mathbf{1 2 \%}$ \\
Serratiamarcescens & $\mathbf{0}$ & $\mathbf{0}$ & $\mathbf{1}$ & $\mathbf{4 \%}$ \\
Citrobacterdiversus & $\mathbf{1}$ & $\mathbf{4 \%}$ & $\mathbf{0}$ & $\mathbf{0}$ \\
Proteus mirabilis & $\mathbf{1}$ & $\mathbf{4 \%}$ & $\mathbf{0}$ & $\mathbf{0}$ \\
Enterobacteraerogenes & $\mathbf{1}$ & $\mathbf{4 \%}$ & $\mathbf{0}$ & $\mathbf{0}$ \\
\hline
\end{tabular}

Table 4: Frequency \% of pathogenic E. coli could be isolated from the examined samples of labenah.

\begin{tabular}{|c|c|c|c|c|c|}
\hline \multirow{3}{*}{ Identified bacterium } & \multicolumn{4}{|c|}{ Products } & \multirow{3}{*}{ Strain characteristic } \\
\hline & \multicolumn{2}{|c|}{ Commercial Labenah } & \multicolumn{2}{|c|}{ Homemade Labenah } & \\
\hline & No./ 0 & $\%$ & No./7 & $\%$ & \\
\hline $0103: \mathbf{H 2}$ & $\mathbf{0}$ & $0 \%$ & 1 & $14.3 \%$ & EHEC \\
\hline O26 : H11 & $\mathbf{0}$ & $0 \%$ & 1 & $14.3 \%$ & EHEC \\
\hline O125: H21 & $\mathbf{0}$ & $0 \%$ & 1 & $14.3 \%$ & ETEC \\
\hline O26 : H11 & $\mathbf{0}$ & $0 \%$ & 1 & $14.3 \%$ & EHEC \\
\hline O55: H7 & $\mathbf{0}$ & $\mathbf{0 \%}$ & 1 & $14.3 \%$ & EPEC \\
\hline 091 & $\mathbf{0}$ & $0 \%$ & 1 & $14.3 \%$ & EPEC \\
\hline O125: H21 & $\mathbf{0}$ & $0 \%$ & 1 & $14.3 \%$ & ETEC \\
\hline TOTAL & 0 & $0 \%$ & 7 & $100 \%$ & \\
\hline
\end{tabular}

\section{DISCUSSION}

Examination of commercial Labenah samples for detection of total yeast and molds count, revealed that 5 sample were positive in percentage of $20 \%$ with average count of $8.8 \times 10^{2} \mathrm{cfu} / \mathrm{g}$, while the samples of homemade Labenah were counted in $28 \%$ (7 samples) with average count $6 \times 10^{2}$ and minimum of $<100$ and maximum of $4 \times 10^{3} \mathrm{cfu} / \mathrm{g}$ (table1). The results are online with those reported by AlKadamany et al. (2002) who stated that psychrotrophic yeasts increased in stored Labenah at 5 and $15^{\circ} \mathrm{C}$. Yeasts and molds may grow over a wide range of temperature and gain entrance to milk either from the milk used, air contamination or utensils. So, their presence is indicative of unsatisfactory sanitation during processing and handling of the product. The high level of these microorganisms may be due to post pasteurization contamination (Mihyar et al., 1997).

Low count of total yeasts and molds count in commercial labenah may be due to Lactic acid bacteria $(\mathrm{LAB})$ occur naturally in labenah or are added as pure cultures to products. They are considered to be harmless or even to have an advantage for human health (probiotics) (Stiles et al., 2002). LAB are well known for their use as starter cultures in the manufacture of dairy products such as acidophilus milk, yoghurt, buttermilk, cottage cheeses, hard cheeses (Cheddar and Edam) and soft cheeses (Brie and Camembert) (Carr et al., 2002). Lactic and acetic acids are produced as end products during lactic acid bacterial fermentation causing a reduction in $\mathrm{pH}$, but other substances such as hydrogen peroxide, formic acid, propionic acid, acetoin and diacetyl, are also produced (Lindgren and Dobrogosz, 1990). Studies on the effect of LAB on fungi are complicated by the fact that some fungi are sensitive to the normal by-products of LABmetabolism, most notably lactic and acetic acids (Piard and Desmazeaud, 1992 and Bonestroo et al., 1993).

The results recorded in Table 2 revealed that, coliforms was detected in $28 \%$ of commercial Labenah samples in counts ranging from $<100$ to $9 \mathrm{X}$ $10^{3}$ with an average count of $9.6 \times 10^{2} \mathrm{cfu} / \mathrm{g}$. while, 
from estimated results in the same Table, it is obvious that the coliforms were counted in $72 \%$ (18 samples) of homemade Labenah and counts ranging from $<100$ to $3.15 \times 10^{5}$ with an average count of $7.6 \times 10^{4} \mathrm{cfu} / \mathrm{g}$. Coliforms being non-spore formers should be susceptible to pasteurization. Their post pasteurization presence in the examined samples may be due to either faulty heat process or to post pasteurization contamination by handlers with poor sanitary practices. The presence of these organisms in food had been described as an index of food hygiene (Frazier and Westhoff, 1978; Jay 1978).

The results determined in this study revealed that, out of the 25 samples of homemade Labenah examined, $28 \%$ (7 samples) were positive for pathogenic $E$. coli (Table 3). While, the samples of commercial labenah found to be free from pathogenic E. coli. A decrease in $\mathrm{pH}$ occasioned by the production of organic acids in fermented milk products leads to inhibition of E. coli and other coliforms (Gran et al., 2003). Also, Table (3) gives information about the other microorganisms could be isolated from examined samples were Serratialiquefaciens, Klebsiella pneumonia, Providenciarettgeri, Proteus mirabilis, Enterobacteraerogenes and Serratiamarcescens could be isolated and identified in percentage of $4 \%$, $12 \%, 12 \%, 12 \%, 12 \%$ and $4 \%$ in the examined samples of homemade labenah. In addition, Coliforms which could be detected in examined samples of commercial labenah were Citrobacterdiversus, Proteus mirabilis and Enterobacteraerogenes in percentage of $4 \%, 4 \%$ and $4 \%$ respectively. Enterobacter spp., particularly E. aerogenes, has been associated with nosocomial outbreaks, and is considered opportunistic pathogens. The detection of Enterobacteraerogenes, Klebsiella, and Serratia species in commercial and homemade Labenah as the case may be, indicates possible faecal contamination. Being enteric bacteria, their presence indicates poor hygienic practices among handlers of commercial and homemade Labenah. Due to the significance of the faecal-oral route transmission for many bacterial food-borne diseases, basic hygiene measures assume a decisive importance in food safety management (Utermann, 1998).

Enterobacteriaceae are normally associated with poor hygiene and their presence may be a pointer toward a potential health risk. Dirar (1993) observes that lack of pasteurization in traditionally fermented milk products is a major risk-enhancing factor. Even though the milk is boiled for prolonged periods of time, this is insufficient to minimize the risk of contamination, coliforms were still detected, an indication of post heat treatment contamination. Enterobacter spp. can cause numerous infections, including cerebral abscess, pneumonia, meningitis, septicemia, and wound, urinary tract (particularly catheter-related UTI), and abdominal cavity/ intestinal infections. In addition, Enterobacter spp. has been noted in intravascular device-related infections, and surgical site infections (primarily postoperative or related to devices such as biliary stents). Many species can cause extra-intestinal infections (Pagotto et al., 2003 and Farmer et al., 2007).

Other strains of E. coli could be isolated and identified with serodiagnosis were documented in Table 4 where O103: H2(EHEC), O26: H11(EHEC), O125: H21(ETEC), O26: H11(EHEC), O55: H7(EPEC), O91(EPEC) and O125:H21(EHEC) in frequency percentage of $14.3 \% ; 14.3 \% ; 14.3 \%$; $14.3 \% ; 14.3 \% ; 14.3 \%$ and $14.3 \%$ respectively, in the examined samples of homemade labenah. Riley et al. (1983) stated that enterohaemorrhagic E. coli is a new emerging pathogen causing two principle types of illness in human, Hemorrhagic Colitis (HC) and Hemolytic Uremic Syn-drome (HUS). It was firstly identified as a cause of human illness in 1982 when it was associated with two food related outbreaks of $\mathrm{HC}$ in the states of Oregon (26 cases) and Michigan (21 cases). Varnam and Evans (1991) subdivided the pathogenic strains of $E$. coli on the basic of clinical symptoms, mechanisms of pathogenesis, biochemical and serological markers into five groups: enteropathogenic (EPEC), enterotoxigenic (ETEC), enteroinvasive (EIEC), enteroaggregative, and enterohaemorrhagic (EHEC). While, Piercefield et al. (2010) stated that one of the common nonO157 VTEC in the USA is O111:H8 and one of the largest outbreaks was caused by an EHEC O111 in the USA in 2008 causing 341 illnesses.

The higher microbial load may be due to contamination during post-preparation handling, transportation and storage of the finished product. The method of production, handling, transportation and marketing of the homemade products are entirely depend upon traditional method. Such method could pose favorable environment for bacterial contamination. The unclean hands of workers, poor quality of milk, unhygienic conditions of manufacturing unit, inferior quality of material used and water supplied for washing the utensils could be the source of accelerating the bacterial contamination of milk products and post manufacturing contamination (Kulshrestha, 1990).

In the present study, the bacteriological evaluation of homemade Labenah found to be contaminated with different bacterial pathogens like pathogenic E. coli, coliforms and mold and yeast. All these bacterial pathogens are responsible for the food borne and diarrheal diseases. The Local Government and the ministry should consider establishment of adequate facilities and utility services as well as provision of necessary information, education and training programmes for consumers. 


\section{REFERENCES}

A.P.H.A. (1992): Standard Methods for the Examination of Dairy Products. 13th Ed., American Public Health Association. Academic Press: 2062-2065.

Akabanda, F.; Owusu-Kwarteng, J.; Tano-Debra, K. and Glover, R.L.K. (2013): Taxonomic and molecular characterization of lactic acid bacteria and yeasts in nunu, a Ghanaian fermented milk product. Food Microbiol. 34: 277-283.

Abd El-Salam, M.H.; Hippen, A.R.; El-Shafie, K.; Assem, F.M.; Abbas, H.; Abd El-Aziz, M.; Sharaf, O. and El-Aassar, M. (2011): Preparation and properties of probiotic concentrated yoghurt (labneh) fortified with conjugated linoleic acid. International Journal of Food Science and Technology, 46(10), 2103-2110.

Al-Kadamany, E.; Toufeili, I.; Khattar, M.; AbouJawdeh, Y.; Harakeh, S. and Haddad, T. (2002): Determination of shelf life of concentrated yogurt (labneh) produced by inbag straining of set yogurt using hazard analysis. J. Dairy Sci., 85: 1023-1030.

Beukes, E.M.; Bester, B.H. and Mostert, J.F. (2001): The microbiology of South African traditional fermented milks. Int. J. Food Microbiol. 63: 189-197.

Bonestroo, M.H.; Dewit, J.C.; Kusters, B.J.M. and Rombouts, F.M. (1993): Inhibition of the growth of yeasts in fermented salads. International Journal of Food Microbiology 17, 311-320.

Carr, F.J.; Chill, D. and Maida, N. (2002): The lactic acid bacteria: a literature survey. Critical Reviews in Microbiology 28, 281370.

Dilielo, L.R. (1982): Methods in Food and Dairy Microbiology. AVI publishing Co. Inc. Westport Connt, USA, pp: 39.

Dirar, H.A. (1993): The indigenous fermented foods of the Sudan. A study in African fermented foods and nutrition. CAB International, Wallingford, UK.

El-Baradei, G.; Delacroix-Buchet, A. and Ogier, J.C. (2008): Bacterial diversity of traditional zabady fermented milk. Int. J. Food Microbiol. 121: 295-30.

El Samragy, Y.A. (1997): Labneh or yoghurt cheese: a review. Egyptian J. Dairy Sci. 25: 165-178.

Farmer, J.J.; Boatwright, K.D. and Janda, J.M. (2007): Enterobacteriaceae: Introduction and identification. In P. R. Murray, E. J. Baron, J. H. Jorgensen, M.L. Landry and M.A. Pfaller (Eds.), Manual of Clinical microbiology (9th ed., pp. 649-669). Washington, DC, USA: ASM press.
Franck, S.M.; Bosworth, B.T. and Moon, H.W. (1998): Multiplex PCR for enterotoxigenic, attaching and effacing, and Shiga toxinproducing Escherichia coli strains from calves. J. Clin. Microbiol., 36: 1795-1797.

Frazier, W.C. and Westhoff, D.C. (1978): Food Microbiology. $3^{\text {rd }}$ Edition. Hill Publishing Co. New York.

Gonfa, A.; Fite, A.; Urga, K. and Gashe, B.A. (1999): The microbiological aspects of ergo (ititu) fermentation. SINET. Ethiop. J. Sci. 22:2.

Gran, H.M.; Gadaga, H.T. and Narvuhs, J.A. (2003): Utilization of various starter cultures in the production of amasi, a Zimbabwean naturally fermented raw milk product. Int. J. Food Microbiol. 88:19-28.

Gyles, C.L.: Escherichia coli. In: Gyles, C.L. and Thoen, C.O. (Eds.) (1993): Pathogenesis of Bacterial Infections in Animals. Iowa Stat University Press, Ames, Iowa, 164-187.

Harrigan, W.F. and McCance, M.E. (1976): Laboratory Methods in Food and Dairy Microbiology. Academic Press Inc., London.

Kaper, J.B.; Nataro, J.P. and Mobley, H.L. (2004): Pathogenic Escherichia coli. Nature Reviews Microbiology, v. 2, p.123-140.

Kok, T.; Worswich, D. and Gowans, E. (1996): Some serological techniques for microbial and viral infections. In Practical Medical Microbiology (Collee, J.; Fraser, A.; Marmion, B. and Simmons, A., eds.), $14^{\text {th }}$ ed., Edinburgh, Churchill Livingstone, UK.

Kulshrestha, S.B. (1990): Prevalence of enteropathogenicsero groups of E.coli in milk products samples from Bareilly and their multiple drug resistance. Ind. J. Dairy Sci. 43: 337-338.

Lore, T.A.; Mbugua, S.K. and Wangoh, J. (2005): Enumeration and identification of micrflora in suusac, a Kenyan traditional fermented camel milk product. LWT 38: 125-130.

Lindgren, S.E. and Dobrogosz, W.J. (1990): Antagonistic activities of lactic acid bacteriain food and feed fermentations. FEMS Microbiology Reviews 87, 149-164.

Mathara, J.M.; Schillinger, U.; Guigas, C.; Franz, C.; Kutima, P.M. and Mbugua, S.K. (2008): Functional characteristics of Lactobacillus spp. from traditional Maasai fermented milk products in Kenya. Int. J. Food Microbiol. 126: 57-64.

Mihyar, G.F.; Yamani, M.I. and Al-Saed, A.K. (1997): Resistance of yeast flora of labaneh to potassium sorbate and sodium benzoate. J. Dairy Sci., 80: 2304-2309.

Muir, D.D. and Banks, J.M. (2000): Milk and milk products. Pp.197-219 in the stability and shelf life of food. D. Klicast and P. Subramanian 
ed. CRC Press, Boca Raton, FL. (4)14: 530542.

Nagy, B. and Fekete, P.Z. (1999): Enterotoxigenic Escherichia coli (ETEC) in farm animals. Vet. Res., 30: 259-284.

Njage, P.M.K.; Dolci, S.; Jans, C.; Wangoh, J.; Lacroix, C. and Meile, L. (2011): Characterization of yeasts associated with camel milk using phenotypic and molecular identification techniques. Res. J. Microbiol. 6: 678-692.

Nsabimana, C.; Jiang, B. and Kossah, R. (2005): Manufacturing, properties and shelf life of labneh: a review. International Journal of Dairy Technology, 58(3), 129-137.

Özer, A.H. and Robinson, R.K. (1999): The behaviour of starter cultures in concentrated yogurt (Labneh) produced by different techniques. Lebensmittel-Wissenschaft undTechnologie, 32 ،391-395 ،doi: 10.1006/ fstl.1999.0566.

Pagotto, F.J.; Nazarowec-White, M.; Bidawid, S. and Farber, J.M. (2003): Enterobactersakazakii: infectivity and enterotoxin production in vitro and in vivo. Journal of Food Protection174, 66 (3), 370-375.

Piard, J.C. and Desmazeaud, M. (1992): Inhibiting factors produced by lactic acid bacteria. 2 . Bacteriocins and other antibacterial substances. Lait 72, 113-142.

Piercefield, E.; Archer, P.; Kemp, P. and Malllonee, $S$. (2010): Increase in unintentional medication overdose deaths-Oklahoma, 1994-2006. Am. J. Prev. Med. 39: 357-363.

Quinn, P.J.; Morkey, B.K.; Cater, M.E.; Donelly, W.J.C. and Leonard, F.C. (2002): Veterinary Microbiology and Microbial Diseases. 1st Iowa Stat University Press Blackwell Science.

Ray, B. and Speck, M.L. (1978): Plating procedure for the enumeration of coliforms from dairy products. Appl. and Enviroment., 35(4): 820822.

Riley, L.W.; Remis, R.S.; Helgerson, S.D.; McGee, H.B.; Wells, J.G.; Davis, B.R.; Hebert, R.J.; Olcott, E.S.; Johnson, L.M.; Hargrett, N.T.; Blake, P.A. and Cohen, M.L. (1983): Hemorrhagic colitis associated with a rare Escherichia coli serotype. New England Journal of Medicine.; 308(12): 681 - 685.

Salji, J.P.; Sawaya, W.N. and Ayaz, M. (1987): The dairy processing industry in the central province of Saudi Arabia. Dairy Food Sanit. 7: 6-13.

Sharaf, O.M.; Mehanna, N.S.; El-Shafei, K.A. and Metwally, A.E. (1996): Effect of using different starters on quality of Labneh. Annals. Agric. Sci., Ain Shams Univ., Cairo, 1996, 41, 901-912.

Stiles, J.; Penkar, S.; Plockova, N.; Chumchalova, J. and Bullerman, L.B. (2002): Antifungalactivity of sodium acetate and Lactobacillus rhamnosus. Journal of Food Protection 65, 1188-1191.

Tamime, A.Y. and Robinson, R.K. (1999): Yoghurt science and technology (pp. 326-333). Boca Raton, FL: CRC Press.

Tamime, A.Y.; Davies, G.; Chehade, A.S. and Mahdi, H.A. (1989): The production of 'labneh' by ultrafiltration: A new technology. J. Soc. Dairy Technol. 42: 35-39.

Varnam, A.H. and Sutherl and, J.P. (1994): Milk and Milk Products. Technology, Chemistry and Microbiology. Chapman and Hall, London.

Varnam, A.H. and Evans, M.G. (1991): Food-borne Pathogens. An illustrated text. Published by Wolfe Publishing Ltd., England.

Utermann, F. (1998): Microbial hazards of food. Food Controll.; 119: 126.

\section{دراسة مقارنة بين الجودة الميكروبيولوجية للبنة التجارية والمنزلية}

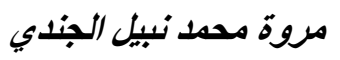

Email: $\underline{\text { moazahmednofel@yahoo.com }}$

Assiut University web-site: www.aun.edu.eg

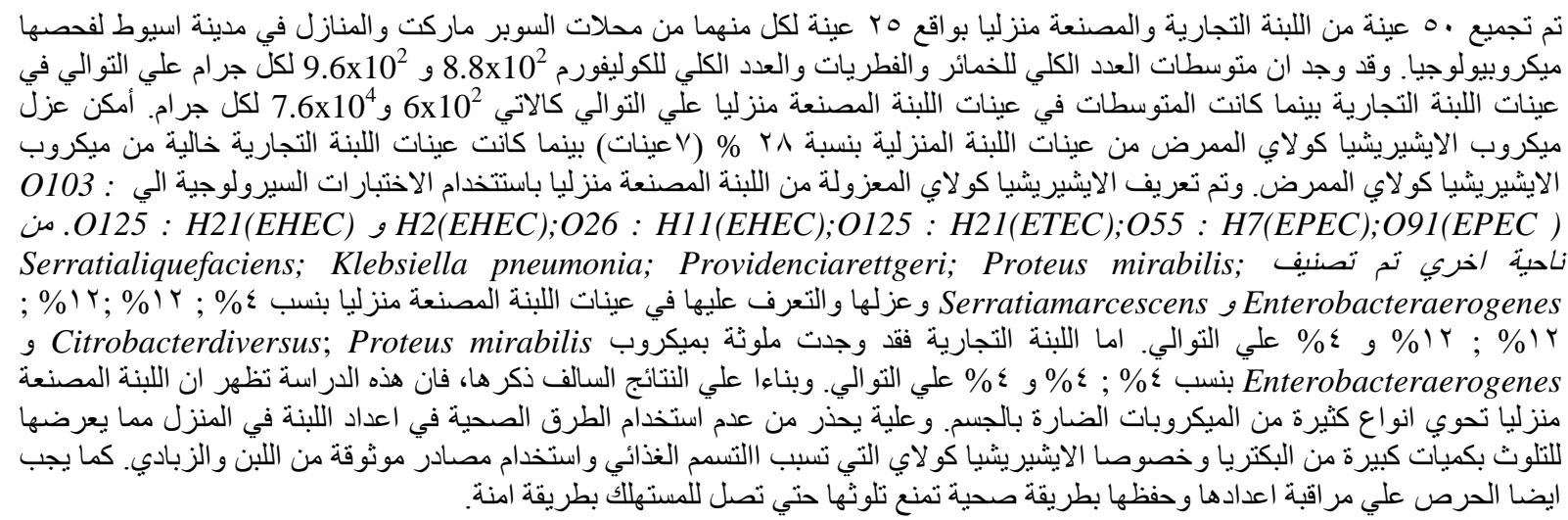

